\title{
Rapid and Inexpensive Colorimetric Detection of Total Serum Protein Using Microzone Plates Wax-Printed on Polyester Films
}

\author{
Karoliny A. Oliveira, ${ }^{a}$ Thiago M. G. Cardoso, ${ }^{a}$ Helton F. Oliveira, ${ }^{b}$ \\ Maria C. S. Fioravanti ${ }^{\circledR b}$ and Wendell K. T. Coltro ${ }^{\circledR *, a, c}$ \\ ${ }^{a}$ Instituto de Química, Universidade Federal de Goiás, 74690-900 Goiânia-GO, Brazil \\ ${ }^{b}$ Escola de Veterinária e Zootecnia, Universidade Federal de Goiás, 74690-900 Goiânia-GO, Brazil \\ 'Instituto Nacional de Ciência e Tecnologia de Bioanalítica, 13084-971 Campinas-SP, Brazil
}

\begin{abstract}
This report describes a rapid and inexpensive colorimetric method based on biuret assay for total serum protein analysis using wax printed microzone plates and a desktop scanner. The colorimetric assay was performed in 96-microzone plates fabricated on polyester films through a wax printing protocol. The image scanning mode and the concentration of the biuret reagents were optimized to achieve the highest detectability levels. The best analytical response was obtained using the slide scanning mode as well as $4 \% \mathrm{CuSO}_{4}$ and $150 \mathrm{mmol} \mathrm{L}^{-1}$ potassium sodium tartrate solutions. The proposed method offered linear relationship for the bovine serum albumin concentration range between 25 and $200 \mu \mathrm{mol} \mathrm{L}{ }^{-1}$ with a limit of detection of $9.7 \mu \mathrm{mol} \mathrm{L} \mathrm{L}^{-1}$. The colorimetric approach revealed satisfactory precision (relative standard deviation values between 0.6 and $4.4 \%$ ). The bioanalytical feasibility was demonstrated through the total protein analysis in serum samples collected from dogs previously diagnosed with kidney disease. The total serum protein concentrations varied from $960 \pm 19$ to $1661 \pm 38 \mu \mathrm{mol} \mathrm{L} \mathrm{L}^{-1}$ and the achieved values revealed good accordance with those obtained through a reference method. Based on the reported results, wax printed microzone plates have demonstrated simplicity and potential to be adopted as alternative platforms for bioassays.
\end{abstract}

Keywords: bioanalytical chemistry, biuret assay, kidney diseases, spot test, wax printing

\section{Introduction}

Total protein analysis represents an useful parameter for routine clinical screening. ${ }^{1}$ The access to the concentration levels of total serum proteins is essential for preventing, diagnosing and monitoring a few pathological disorders since they may be an indicator for detecting kidney failure or disease and chronic infection. ${ }^{2-4} \mathrm{Gel}$ electrophoresis is well-established as a gold-standard diagnostic tool allowing to identify abnormalities based on the serum protein fraction profile. However, the protein analysis through conventional gel electrophoresis is time-consuming and it usually requires a gel staining step prior to the detection stage. $^{5-7}$

Alternative methods involving spectrophotometric measurements have emerged as powerful strategies to provide faster information on the total protein concentration. ${ }^{8,9}$ Most of the assays reported in the

*e-mail: wendell@ufg.br literature $^{10,11}$ are known as Bradford, Lowry and biuret methods. While the Bradford reaction is the simplest, the Lowry method is considered the most sensitive. ${ }^{12,13}$ However, the latter is liable to interferences from the matrix and it requires an accurate control of the operation time. ${ }^{4} \mathrm{On}$ the other hand, the biuret method offers high accuracy, low chemical interference and no dependence on the amino acid composition. ${ }^{14}$ In summary, the biuret assay is employed to detect the presence of peptide bonds. The $\mathrm{Cu}^{2+}$ ion reacts in alkaline medium with proteins forming a tetracoordinated complex with adjacent peptide groups. ${ }^{4,15,16}$ The reaction product presents a violet coloration and its intensity is proportional to the concentration of proteins in solution. The reaction is performed in the presence of potassium sodium tartrate as a stabilizer reagent.

The aforementioned assays are often performed by conventional spectrophotometry. ${ }^{17}$ In the last years, simple and inexpensive electronic instruments have received considerable attention to be used for colorimetric measurements. ${ }^{18-21}$ Cell phone cameras, digital cameras 
and benchtop scanners have been successfully adapted to be used in association with microwell plates, spot test arrays and microfluidic devices. ${ }^{22,23}$ It is important to highlight that commercially available microwell plates, usually dedicated to enzyme-linked immunosorbent assays, have been great platforms for chemical and biochemical assays especially due to its easy integration with scanners, cell phone or digital cameras. ${ }^{24}$ The sample volume required to fill a microwell in the commercial plates is typically between 50 and $200 \mu \mathrm{L}$. In the last decade, wax and laser printing technologies have become increasingly popular to fabricate microzone plates and microfluidic devices on low-cost materials including paper and polyester substrates. ${ }^{25,26}$ In comparison with commercial microwell plates, the use of printed microzone plates or spot test arrays requires lower volume of sample and consequently generates reduced amount of waste. Additionally, printed microzones have revealed good performance for bioanalytical applications including protein analysis in different biological fluids. ${ }^{27-29}$

In this current study, we describe a rapid and inexpensive colorimetric assay based on biuret method to determine the concentration levels of total proteins in serum samples using microzone plates wax printed on polyester films. The concentrations of the reagents employed in the biuret assay were optimized to offer the best analytical sensitivity. The resulting images were digitalized using a desktop scanner and the digital image analysis was performed in the Corel Photo-Paint software. ${ }^{30}$ The bioanalytical feasibility was successfully demonstrated through the total protein analysis in serum samples collected from dogs previously diagnosed with kidney disease. The achieved data revealed good accordance with the results obtained through a reference technique. Based on the reported study, the use of wax printed microplates for total protein analysis based on biuret assay is quite promising and it has offered high potential to be adopted as alternative method for rapid screening in veterinary applications.

\section{Experimental}

\section{Chemicals and materials}

Copper(II) sulfate pentahydrate, potassium sodium tartrate, sodium hydroxide, methylene blue, sodium phosphate monobasic anhydrous, sodium phosphate dibasic anhydrous and bovine serum albumin (BSA) were acquired from Sigma-Aldrich (St. Louis, MO, USA). All chemicals were used as received and without further purification. All standard solutions were prepared in ultrapure water processed through a water purification system (Direct- $Q^{\circledR} 3$,
Millipore, Darmstadt, Germany) with resistivity equal to $18.2 \mathrm{M} \Omega \mathrm{cm}$. Stock solutions of BSA $\left(1 \mathrm{mmol} \mathrm{L}^{-1}\right)$ were prepared daily in $100 \mathrm{mmol} \mathrm{L}^{-1}$ phosphate buffer ( $\left.\mathrm{pH} 7.0\right)$.

Transparency films (Filipaper Pro $100-\mu$ model) and office scanner (model Scanjet G4050) were obtained from Filiperson (Rio de Janeiro, RJ, Brazil) and Hewlett-Packard (Palo Alto, CA, USA), respectively. The artificial serum samples (levels I and II) were obtained from Biotécnica Ltda. (Varginha, MG, Brazil). A commercial colorimetric kit for total protein assay was purchased from Labtest Diagnóstica S.A. (Lagoa Santa, MG, Brazil).

\section{Canine serum samples}

Canine serum samples $(n=5)$ were received from the Veterinary Hospital of the School of Veterinary and Animal Science at the Federal University of Goiás (Goiânia, GO, Brazil). Three samples were collected from dogs previously diagnosed with kidney diseases and two samples were collected from healthy dogs. It was chosen dogs of different ages and gender including four males and one female.

All the studies with canine serum samples were carried out in accordance with the Animal Research Ethics Committee from the Federal University of Goiás (CEUA/ UFG) (No. 007/16).

\section{Fabrication on the wax-based microzone plates}

Wax printed microzone plates were fabricated on polyester films. The microplate layout containing 96 zones arranged into 12 columns with 8 zones each was drawn in the Corel Draw software ${ }^{31}$ and directly printed on a polyester film using a Xerox wax printer (model ColorQube 8570, Rochester, NY, USA). The total protein colorimetric assay was carried out on printed zones defined with $7 \mathrm{~mm}$ diameter and delimited by wax lines printed with $1 \mathrm{~mm}$ width.

\section{Total protein assay on wax printed microplates}

The total protein assay was performed according to the procedure described by Gornall et al. ${ }^{15}$ Briefly, $100-\mu \mathrm{L}$ aliquots of $4 \%(\mathrm{~m} / \mathrm{v})$ copper(II) sulfate pentahydrate, $3.0 \mathrm{~mol} \mathrm{~L}^{-1}$ sodium hydroxide and $0.15 \mathrm{~mol} \mathrm{~L}^{-1}$ potassium sodium tartrate solutions were mixed to prepare the chromogenic reagent, also known as biuret reagent. Then, a $10-\mu \mathrm{L}$ aliquot of the chromogemic reagent was added into each microzone. Afterwards, a $20-\mu \mathrm{L}$ aliquot of BSA standard solution, prepared in $100 \mathrm{mmol} \mathrm{L}^{-1}$ phosphate buffer ( $\mathrm{pH}$ 7.0), or canine serum sample was added into each zone. 


\section{Colorimetric detection}

For colorimetric detection, all images were scanned at the slide mode using a 600-dpi resolution. The digitalization was performed $5 \mathrm{~min}$ after adding the chromogenic reagent and sample. Digital images were converted to CMYK scale in the Corel Photo-Paint software ${ }^{30}$ and the arithmetic mean of pixel intensity wax extracted within each zone using the magenta color channel. The colorimetric response was explored to determine the total protein concentration in serum samples. Figure 1 summarizes the procedure adopted to perform the colorimetric assay for detecting total protein in serum samples.

A conventional automatic biochemistry analyzer model CM 200 (Wiener lab Group ${ }^{\circledR}$, Rosario, Argentina) was chosen to proceed the protein total analysis using the commercial colorimetric kit from Labtest ${ }^{\circledR}$. The readout was carried out at $546 \mathrm{~nm}$ and the results were used to compare the data obtained on wax printed microplates.

\section{Results and Discussion}

In previous reports, ${ }^{27-29}$ our group described the fabrication of microzone plates on polyester substrates through laser printing technology, which enabled the deposition of toner barriers with ca. $5.0 \pm 0.4 \mu \mathrm{m}$ thickness. In this current study, the fabrication of the microzone plates was performed by wax printing. ${ }^{32}$ Similar to laser printing, the use of a wax printer has also allowed the direct fabrication microzone array on polyester films in a single step. The main difference refers to the barrier thickness. According to profilometric measurements, the wax barrier printed on polyester exhibited a thickness of $18 \pm 2 \mu \mathrm{m}$ (data not shown). A comparison between the microzones defined with toner and wax barriers was performed varying the volume (10-60 $\mu \mathrm{L})$ of a dye solution (methylene blue) added inside each microzone. As it can be seen in Figure 2a, the different aliquots of dye solution remained confined inside microzones created with toner and wax barriers immediately after the addition. However, it was observed leakage of the solution to neighboring zones defined with toner barriers for volumes larger than $50 \mu \mathrm{L}$ (Figure $2 \mathrm{~b}$ ). In this way, wax barriers demonstrated better effectiveness to retain larger volumes of solution inside microzones due probably to their higher thickness in comparison with toner barriers.

The colorimetric assay for total protein analysis based on the biuret assay was performed on polyester microzone plates using a desktop scanner. Aiming to achieve the best performance prior to the real sample analysis, the image scanning mode as well as the concentrations of reagents used to prepare the biuret reagent were thoroughly optimized prior to the analysis of total proteins in artificial and canine serum samples.

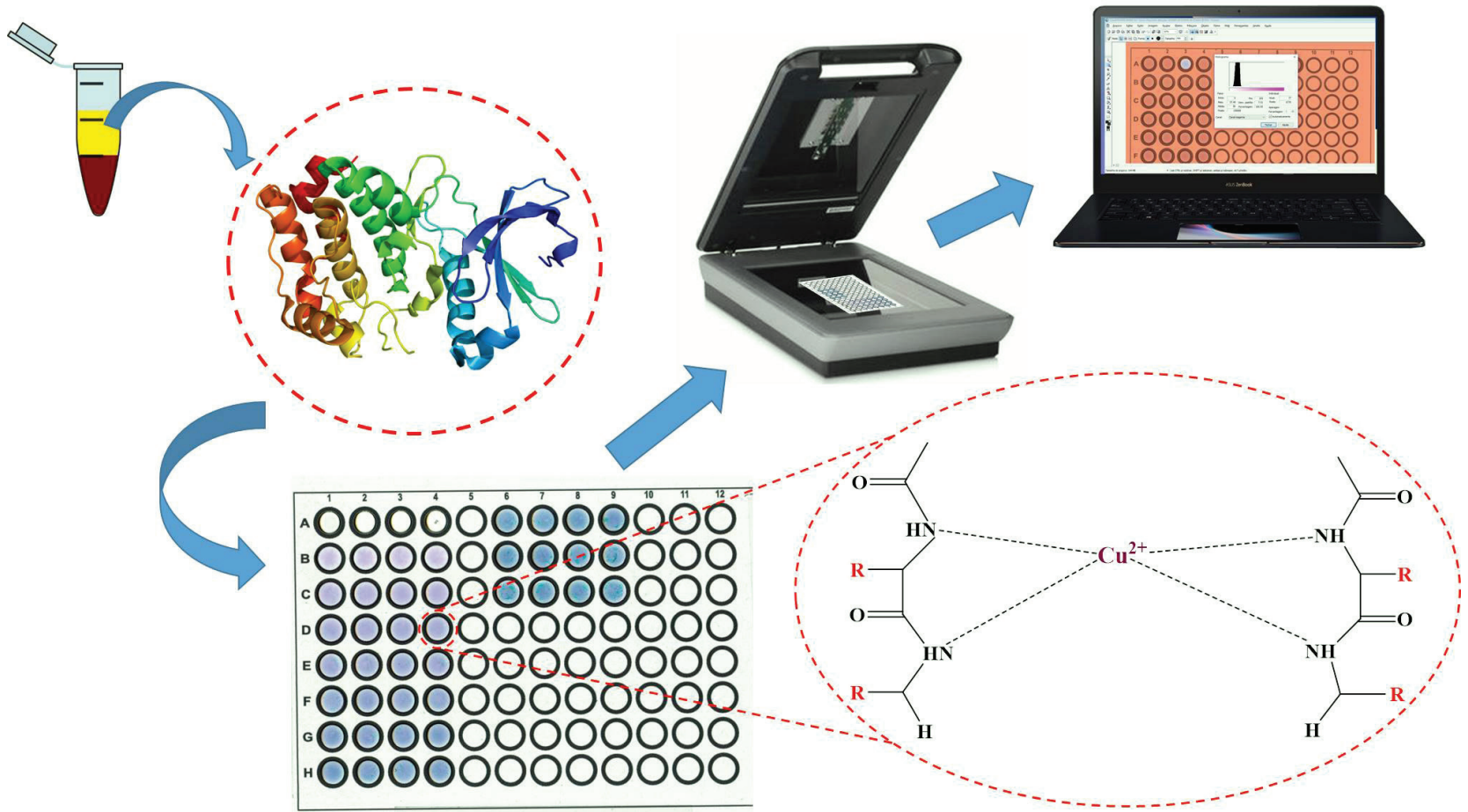

Figure 1. Representation of experimental setup for colorimetric assay for total protein analysis in serum samples. First, the blood serum is collected, and an aliquot is added inside each microzone previously prepared with the biuret reagent. After the color development, the image is digitalized using a desktop scanner and the pixel intensity is extracted through the Corel Photo-Paint software. ${ }^{30}$ 
(a)

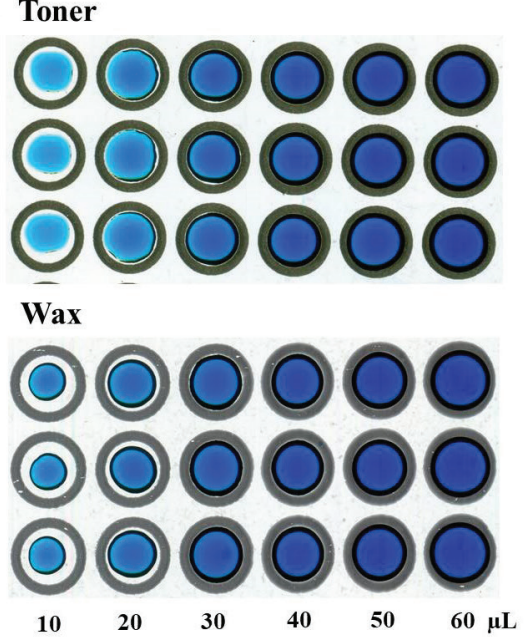

(b)
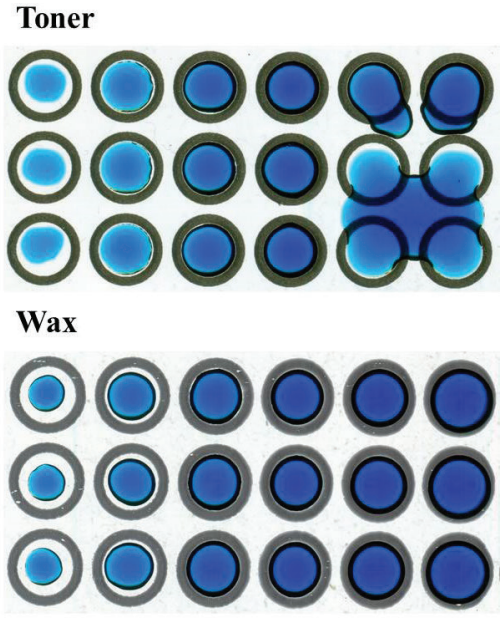

Figure 2. Effectiveness of toner and wax printed microzones on polyester films for confining different volumes (from 10 to $60 \mu \mathrm{L}$ ) of a methylene blue solution added inside microzones. Images depicted in (a) and (b) show the performance of printed zones at 0 and 10 min, respectively, after adding the solution.

Image scanning mode

In the last decade, scanner has been widely used as instrument for colorimetric detection on simple and portable analytical devices. ${ }^{33-35}$ When compared to other conventional equipment including a microplate reader and a spectrophotometer, scanners are relatively cheaper. Furthermore, the lighting control and the robustness are some advantages which justify the increasing popularity of scanners for capturing digital images on different analytical platforms. ${ }^{17}$

The scanner used in this current study offers the possibility to promote the scanning in two modes, namely normal and slide modes. The normal scanning mode is the most common way to obtain digital images based on the scanning at the bottom side of the desirable object. On the other hand, when the scanner is adjusted to operate in the slide mode, also called as transparency mode, the white light from the lid (top side) passes through the wax-printed microplate towards the light sensors located at the bottom surface. ${ }^{36}$ Since the stray light is blocked, the digital image recorded under this mode is relatively clearer and sharper.

A comparison of both scanning modes was performed using standard solutions of BSA prepared at the concentration range between 0 and $400 \mu \mathrm{mol} \mathrm{L}{ }^{-1}$. As can be seen in Figures $3 \mathrm{~A}$ and $3 \mathrm{~B}$, the colorimetric response exhibited a linear behavior for both normal and slide modes. However, a clear difference can be noted in the optical images presented inset each figure. The slide mode has minimized the presence of shadow and shine, thus resulting in better color uniformity inside each microzone. Based on the improved image quality, the slide mode has been selected for the subsequent experiments aiming the detection of total protein in serum samples using microplates wax-printed on polyester films. It is important to highlight that a cell phone camera could be also used to capture the digital image. However, it is quite susceptible to interferences associated to light, shine, camera focus and distance for image capture. For these reasons, the use of a scanner was preferred to evaluate the bioanalytical feasibility of the proposed approach.

\section{Optimization of the biuret reagent}

The biuret reagent is a key parameter for the total protein assay and for this reason, the concentrations of copper sulfate and potassium sodium tartrate were optimized since they affect the overall response. Initially, the concentration of the copper sulfate was ranged from 0 to $10 \%$ and the colorimetric response was recorded using a standard solution of BSA prepared at $200 \mu \mathrm{mol} \mathrm{L} \mathrm{L}^{-1}$ keeping constant the potassium sodium tartrate concentration at $250 \mathrm{mmol} \mathrm{\textrm {L } ^ { - 1 }}$. The obtained results are presented in Figure $3 \mathrm{C}$, in which each point and the error bars represent the mean and standard deviation values, respectively, for four independent measurements. As can be seen, the increase in the $\mathrm{CuSO}_{4}$ concentration promoted a rise on the color intensity. However, for concentrations higher than $4 \%$, it was observed the formation of a precipitate of a gelatinous colloid difficult to be solubilized or homogenized even under stirring. As consequence, a non-uniform coloration was obtained inside microzone, thus compromising the colorimetric readout. For this reason, the $\mathrm{CuSO}_{4}$ concentration was kept at $4 \%$ for the subsequent experiments.

The potassium sodium tartrate concentration was also optimized keeping constant the BSA and $\mathrm{CuSO}_{4}$ 

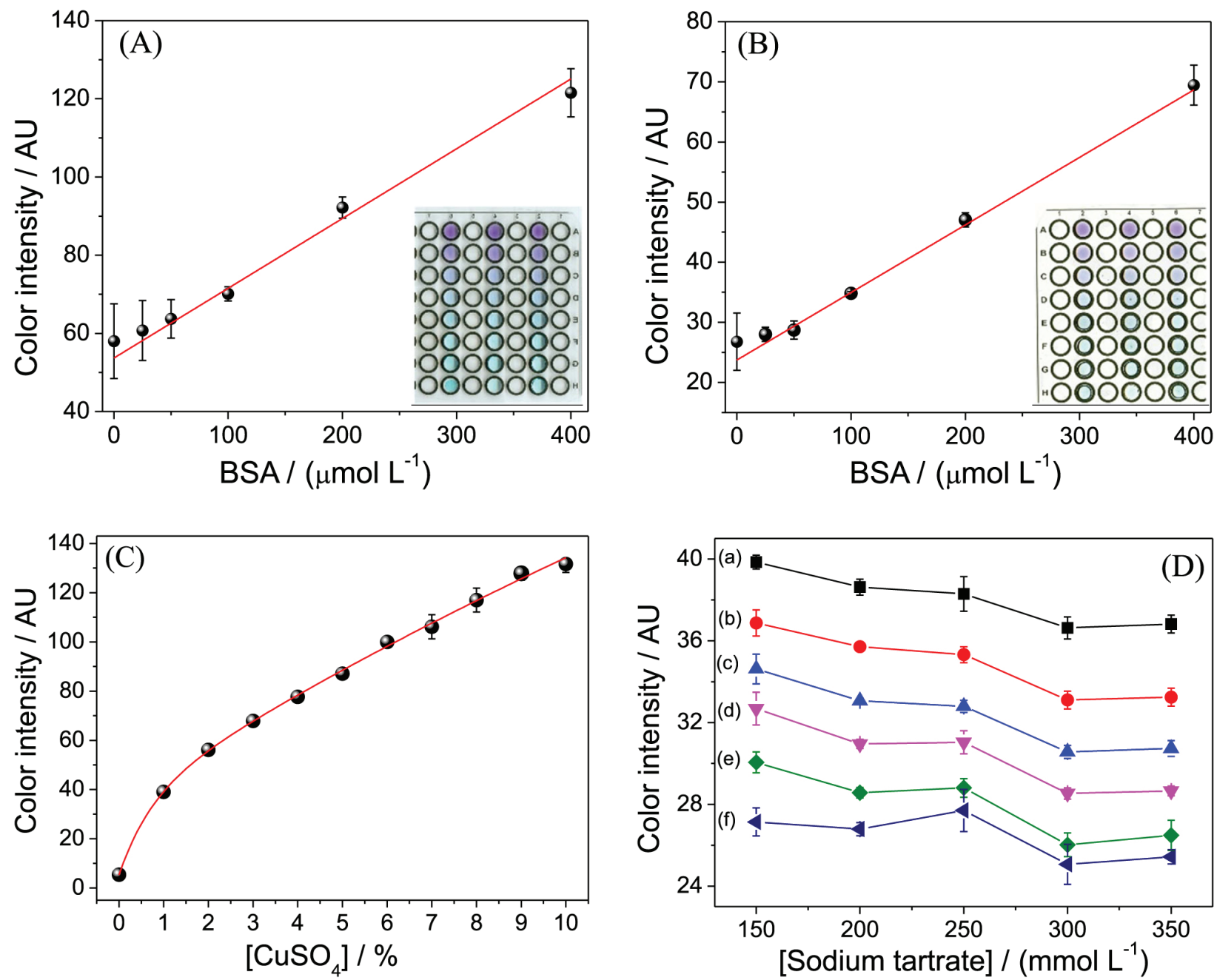

Figure 3. Optimization of the (A, B) image scanning mode and (C, D) biuret reagent concentrations for performing total protein assay. Figures (A) and (B) display the colorimetric response for BSA using normal and slide scanning modes, respectively. The inset micrographs show the resulting digital images recorded for each scanning mode. Graphs (C) and (D) denote, respectively, the effect of the $\mathrm{CuSO}_{4}$ and potassium sodium tartrate concentrations on the color intensity keeping constant the BSA concentration (200 $\mu$ M). In (D), the colorimetric response was monitored over time at (a) 5, (b) 10, (c) 20, (d) 30, (e) 40 and (f) $50 \mathrm{~min}$. The error bars represent the standard deviation values for four independent measurements $(\mathrm{n}=4)$.

concentrations at $200 \mu \mathrm{M}$ and $4 \%$, respectively. The colorimetric measurements were then recorded varying the concentration of the potassium sodium tartrate solution from 150 to $350 \mathrm{mmol} \mathrm{L}^{-1}$ and the obtained results are displayed in Figure 3D. Considering that the biuret assay has demonstrated a strong dependence on the reaction time, colorimetric readouts were also recorded varying the time between 5 and $50 \mathrm{~min}$. As it can be observed in Figure 3D, the increase in the tartrate solution concentration promoted a decrease on the colorimetric response. In addition, the color intensity for each concentration of potassium sodium tartrate gradually decreased from 5 to $50 \mathrm{~min}$. Based on the presented results, the highest colorimetric response was achieved using $150 \mathrm{mmol} \mathrm{L}^{-1}$ potassium sodium tartrate solution and a reaction time of $5 \mathrm{~min}$. This reaction time is enough to guarantee the stabilization of the complex formed between BSA and biuret reagent. ${ }^{15}$

\section{Analytical performance}

The analytical performance of the biuret assay performed on wax printed microzones for detecting total protein using an office scanner as a detection system was investigated using the conditions and parameters previously optimized. For this purpose, the colorimetric response was initially monitored for standard solutions of BSA prepared at the concentration range from 0 to $1000 \mu \mathrm{mol} \mathrm{L}^{-1}$. The images were captured $5 \mathrm{~min}$ after adding the solution inside microzones. The color intensity revealed an exponential behavior with saturation of the analytical response for concentrations higher than $400 \mu \mathrm{mol} \mathrm{L}^{-1}$, as it can be seen in Figure S1 (available in the Supplementary Information (SI) section). For this reason, the behavior of colorimetric measurements was evaluated in a narrower concentration range. As displayed in Figure 4, a linear relationship 
(coefficient of determination $\left(R^{2}\right)=0.997$ ) was observed for the concentration range between 25 and $200 \mu \mathrm{mol} \mathrm{L}^{-1}$. The relative standard deviation (RSD) values were calculated for four replicates performed in the linear concentration range and the achieved results ranged from 0.6 to $4.4 \%$, thus suggesting satisfactory precision for the BSA assays.



Figure 4. Analytical curve for the colorimetric assay ranging the BSA concentration from 0 to $200 \mu \mathrm{mol} \mathrm{L}{ }^{-1}$. The colorimetric response was recorded after a reaction time of $5 \mathrm{~min}$. Error bars represent the standard deviation value $(n=4)$.

The analytical sensitivity and the limit of detection (LOD) achieved were 0.23 (AU per $\mu \mathrm{mol} \mathrm{L}^{-1}$ ) and $9.7 \mu \mathrm{mol} \mathrm{L}{ }^{-1}$, respectively. The LOD value was calculated based on the ratio between three times the standard deviation for the blank and the angular coefficient of the analytical curve. The obtained LOD and the analytical parameters like analytical platform, colorimetric method, sample volume, electronic device used for image capture, linear range and recovery range were compared to other previous reports found in the literature. Based on the comparison summarized in Table 1, the LOD achieved in this current study was considerably higher than the value achieved by Ansari et al. ${ }^{40}$ The difference can be attributed to the employed platform as well as the sample volume. As it can be seen in Table 1, Ansari et al. ${ }^{40}$ performed the protein analysis using Eppendorf tubes with sample volume of $1000 \mu \mathrm{L}$, i.e., 50 -fold larger than the volume used in our study. In addition, it is important to highlight that the LOD obtained using microzone plates wax-printed on polyester films was better than those values reported using biuret methods applied to commercial microplates ${ }^{2,3}$ and paperbased devices ${ }^{38}$ employing cell-phone ${ }^{2}$ and scanners. ${ }^{3,38}$ The best detectability level achieved using the proposed device is related to the optimization of the reagent concentrations as well as the use of a slide scanning mode.

\section{Artificial serum samples}

To demonstrate the bioanalytical feasibility, the total protein concentration was determined in two artificial human serum samples (levels I and II). For this purpose, the serum samples were diluted in water and directly analyzed on wax printed microplate. The total protein concentrations in serum samples were calculated considering the average value of color intensity recorded on four microzones. The achieved concentration levels for both artificial samples as well as the certified values are presented in Table 2 . In comparison with the certified values provided by the supplier, the concentrations found in serum samples revealed an error of 5.8\% (level I) and 9.9\% (level II) for the analyzed samples. The accuracy of the assays performed on wax printed microplates was investigated by spiking the biological samples with standard solutions of BSA prepared at three concentration levels (25, 50 and $75 \mu \mathrm{mol} \mathrm{L}-1)$. Considering the spiking levels, the recovery values were calculated and ranged from 84 to $99 \%$, as can

Table 1. Comparison of the colorimetric methods and analytical information obtained for protein analysis using different platforms and electronic devices for image capture

\begin{tabular}{|c|c|c|c|c|c|c|c|}
\hline Platform & Method & $\begin{array}{c}\text { Sample } \\
\text { volume / } \mu \mathrm{L}\end{array}$ & Image capture & $\begin{array}{l}\text { Linear range }^{\mathrm{a}} / \\
\quad\left(\mu \mathrm{mol} \mathrm{L} \mathrm{L}^{-1}\right)\end{array}$ & $\begin{array}{c}\mathrm{LOD}^{\mathrm{a}} / \\
\left.(\mu \mathrm{mol} \mathrm{L})^{-1}\right)\end{array}$ & $\begin{array}{l}\text { Recovery } \\
\text { range / \% }\end{array}$ & Reference \\
\hline Paper (zone) & biuret & 9 & cell-phone & $151-1,666$ & NR & $82.2-105.3$ & 37 \\
\hline Commercial microplate & biuret & 250 & cell-phone & $38-1,242$ & 12 & $100.6-102.7$ & 2 \\
\hline Commercial microplate & biuret & 250 & scanner & $75.7-606$ & 94 & $54.2-98.3$ & 3 \\
\hline Paper (zone) & biuret & 5 & scanner & $700-4,000$ & 200 & NR & 38 \\
\hline Paper (2D) & ТВРВ & 8 & digital camera & $10-100$ & 5.19 & NR & 39 \\
\hline Paper (3D) & ТВРВ & 10 & digital camera & $5-200$ & 1.26 & NR & 39 \\
\hline Commercial microplate & Bradford & 250 & cell-phone & $3.0-12$ & 1.6 & $87.2-99.1$ & 24 \\
\hline Eppendorf tube & biuret & 1000 & cell-phone & $0.15-4.5$ & 0.2 & $99.4-104.3$ & 40 \\
\hline Polyester film & biuret & 20 & scanner & $25-200$ & 9.7 & $80.4-124.0$ & this work \\
\hline
\end{tabular}

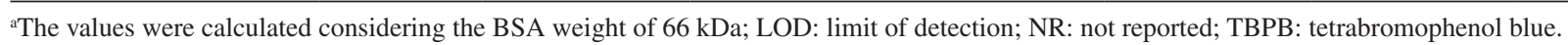


Table 2. Comparison of the total protein concentrations determined in two artificial human serum samples and presentation of the recovery values achieved $(\mathrm{n}=4)$

\begin{tabular}{lcccc}
\hline Serum sample & Certified value $/\left(\mu \mathrm{mol} \mathrm{L}{ }^{-1}\right)$ & Found value / $\left.(\mu \mathrm{mol} \mathrm{L})^{-1}\right)$ & Relative error / \% & Recovery / \% \\
\hline Level I & $624 \pm 24$ & $660 \pm 24$ & 5.8 & $85-99$ \\
Level II & $1099 \pm 110$ & $990 \pm 30$ & 9.9 & $84-87$ \\
\hline
\end{tabular}

Table 3. Comparison of the total protein concentration levels in canine serum samples achieved by spectrophotometry and colorimetric measurements on wax printed microplate $(n=4)$

\begin{tabular}{|c|c|c|c|c|}
\hline Serum sample & Reference method / $\left(\mu \mathrm{mol} \mathrm{L} \mathrm{L}^{-1}\right)$ & Found value / $\left(\mu \mathrm{mol} \mathrm{L} \mathrm{L}^{-1}\right)$ & Relative error / \% & Recovery / \% \\
\hline No. 1 & 983 & $1000 \pm 33$ & 1.7 & $95.4-99.9$ \\
\hline No. 2 & 1110 & $960 \pm 19$ & 13.5 & $80.4-102.6$ \\
\hline No. 3 & 1410 & $1148 \pm 29$ & 18.6 & $98.9-120.0$ \\
\hline No. 4 & 1770 & $1661 \pm 38$ & 6.2 & $101.6-106.4$ \\
\hline No. 5 & 1400 & $1247 \pm 18$ & 11.0 & $102.5-124.0$ \\
\hline
\end{tabular}

be seen in Table 2, thus revealing satisfactory performance bioanalytical assays. The results obtained for each spiking level are presented in Table S1 (available in the SI section).

\section{Total protein analysis in canine serum samples}

As it is well-known, the total protein content in serum plays an important role in the animal health conditions. ${ }^{1}$ Quantification of total serum proteins represents a basic step in general biochemistry and routine clinical laboratory practice, especially because the concentration level of total protein can provide useful information about the health condition including body nutritional status, liver function and renal diseases, for example. ${ }^{1,3,4}$

In this current study, the total protein concentration was determined in five serum samples donated by the Veterinary Hospital, as described in the Experimental section. As it can be seen in Table 3, the concentration of total protein ranged from $960 \pm 19$ to $1661 \pm 38 \mu \mathrm{mol} \mathrm{L}^{-1}$. The achieved values were compared to the data obtained by a reference method and the relative errors ranged from 1.7 to $18.6 \%$. The accuracy of the total protein analysis in canine serum samples performed on wax printed microplates was investigated by spiking the serum samples with standard solutions of BSA at four concentration levels $(25,50,75$ and $100 \mu \mathrm{mol} \mathrm{L}^{-1}$ ). The recovery values ranged from 80 to $124 \%$, as can be seen in Table 2, thus revealing acceptable performance for total protein analysis in canine serum samples. The results obtained for each spiking level are presented in Table S2 (available in the SI section).

Considering the data presented in Table 3, the serum samples collected from healthy dogs (samples Nos. 1 and 2) exhibited total protein concentrations lower than samples from dogs previously diagnosed with kidney diseases (samples Nos. 3, 4 and 5). The concentration values achieved for serum samples from healthy dogs are in good accordance with the literature, ${ }^{41-44}$ since the normal range varies from ca. 55 to $75 \mathrm{~g} \mathrm{~L}^{-1}$ (from 833 to $1136 \mu \mathrm{mol} \mathrm{L}^{-1}$ ). In the same way, the higher concentration levels of total protein observed for samples Nos. 3-5 were somehow expected because this behavior is associated to changes in the membrane (size selectivity) and ionic charge abnormalities (charge selectivity) of kidney filtration, thus resulting in a decrease of the albumin concentration associated to the increase of acute phase proteins, including globulins, common in patients with kidney disease. Based on achieved results, the use of wax printed microplates for determining total protein employing the biuret assay has demonstrated satisfactory performance and it emerges as powerful and simple platform for this kind of application.

\section{Conclusions}

In summary, the fabrication of microzone plates on polyester films through wax printing technology has emerged as a good alternative platform for total serum protein analysis based on a biuret colorimetric assay. The wax barrier (18 $\pm 2 \mu \mathrm{m}$ thick) deposited on the polyester film surface demonstrated to be quite efficient for confining around $30 \mu \mathrm{L}$ of solution (biuret reagent and sample) without sample leakage to neighboring zones. The optimization of the experimental and operational parameters has ensured suitable performance and sensitivity for the analysis of serum samples collected from dogs previously diagnosed with kidney diseases. The data recorded using the proposed approach exhibited good accordance with the results 
obtained by a reference technique, thus revealing great potential for bioanalytical applications.

The instrumental simplicity, the reduced amount of sample and reagent, the low cost per device and the possibility to obtain chemical information about the total protein concentration in short time make the proposed approach quite attractive to be implemented for routine clinical screening. The satisfactory performance has enabled the use of wax-printed microzone plates for studies in veterinary medicine, where the rapid access to the total protein concentration is of paramount importance for monitoring and suitable treatment of animals diagnosed with kidney diseases or failures.

\section{Supplementary Information}

Supplementary data are available free of charge at http://jbcs.sbq.org.br as PDF file.

\section{Acknowledgments}

This study was supported by CNPq (grants 426496/2018-3 and 308140/2016-8), CAPES (grant 3363/2014) and INCTBio (grant 465389/2014-7). CAPES and $\mathrm{CNPq}$ are also thanked for the scholarships and researcher fellowships granted to the authors.

\section{References}

1. Tothova, C.; Nagy, O.; Kovac, G.; Vet. Med. (Prague, Czech Repub.) 2016, 61, 475.

2. Morais, C. L. M.; Neves, A. C. O.; Menezes, F. G.; Lima, K. M. G.; Anal. Methods 2016, 8, 6458.

3. de Morais, C. L. M.; de Lima, K. M. G.; Talanta 2014, 126, 145.

4. Zheng, K.; Wu, L.; He, Z.; Yang, B.; Yang, Y.; Measurement 2017, 112, 16.

5. Li, C.; Arakawa, T.; Int. J. Biol. Macromol. 2019, 125, 566.

6. Ouimet, C. M.; D’Amico, C. I.; Kennedy, R. T.; Anal. Bioanal. Chem. 2019, 411, 6155.

7. Issaq, H. J.; Veenstra, T. D. In Proteomic and Metabolomic Approaches to Biomarker Discovery; Press, A., ed.; Elsevier: United States, 2020, p. 209-214.

8. Chutipongtanate, S.; Watcharatanyatip, K.; Homvises, T.; Jaturongkakul, K.; Thongboonkerd, V.; Talanta 2012, 98, 123.

9. Sapan, C. V.; Lundblad, R. L.; Proteomics: Clin. Appl. 2015, 9, 268.

10. Chang, S. K. C.; Zhang, Y. In Food Science Text Series (FSTS); Nielsen, S., ed.; Springer: Cham, 2017, p. 315-331.

11. Mæhre, H. K.; Dalheim, L.; Edvinsen, G. K.; Elvevoll, E. O.; Jensen, I.-J.; Foods 2018, 7, 5.
12. Redmile-Gordon, M. A.; Armenise, E.; White, R. P.; Hirsch, P. R.; Goulding, K. W. T.; Soil Biol. Biochem. 2013, 67, 166.

13. Okutucu, B.; Dınçer, A.; Habib, Ö.; Zıhnıglu, F.; J. Biochem. Biophys. Methods 2007, 70, 709.

14. Liu, Z.; Pan, J.; Food Chem. 2017, 224, 289.

15. Gornall, A. G.; Bardawill, C. J.; David, M. M.; J. Biol. Chem. 1949, 177, 751.

16. Katsoulos, P. D.; Athanasiou, L. V.; Karatzia, M. A.; Giadinis, N.; Karatzias, H.; Boscos, C.; Polizopoulou, Z. S.; Vet. Clin. Pathol. 2017, 46, 620.

17. Monogarova, O. V.; Oskolok, K. V.; Apyari, V. V.; J. Anal. Chem. 2018, 73, 1076.

18. Huang, X.; Xu, D.; Chen, J.; Liu, J.; Li, Y.; Song, J.; Ma, X.; Guo, J.; Analyst 2018, 143, 5339.

19. Kanchi, S.; Sabela, M. I.; Mdluli, P. S.; Bisetty, K.; Biosens. Bioelectron. 2018, 102, 136.

20. Kaneta, T.; Alahmad, W.; Varanusupakul, P.; Appl. Spectrosc. Rev. 2019, 54, 117.

21. Gee, C. T.; Kehoe, E.; Pomerantz, W. C. K.; Penn, R. L.; J. Chem. Educ. 2017, 94, 941.

22. San Park, T.; Li, W.; McCracken, K. E.; Yoon, J.-Y.; Lab Chip 2013, 13, 4832.

23. Martinez, A. W.; Phillips, S. T.; Carrilho, E.; Thomas III, S. W.; Sindi, H.; Whitesides, G. M.; Anal. Chem. 2008, 80, 3699.

24. de Camargo, C. L.; Vicentini, M. B. R.; Gobbi, A. L.; Martinez, D. S. T.; Lima, R. S.; J. Braz. Chem. Soc. 2017, 28, 689.

25. Morbioli, G. G.; Mazzu-Nascimento, T.; Stockton, A. M.; Carrilho, E.; Anal. Chim. Acta 2017, 970, 1.

26. Gabriel, E. F. M.; Lucca, B. G.; Duarte, G. R. M.; Coltro, W. K. T.; Anal. Methods 2018, 10, 2952.

27. Oliveira, K. A.; de Oliveira, C. R.; da Silveira, L. A.; Coltro, W. K. T.; Analyst 2013, 138, 1114.

28. Oliveira, K. A.; Damasceno, D.; de Oliveira, C. R.; da Silveira, L. A.; de Oliveira, A. E.; Coltro, W. K. T.; Anal. Methods 2016 , 8,6506 .

29. Silva, P. B. M.; Oliveira, K. A.; Coltro, W. K. T.; J. Braz. Chem. Soc. 2017, 28, 197.

30. Corel Photo-Paint, v. 18.1.0.661; Corel Corporation, Canada, 2016.

31. Corel Draw, v. 18.1.0.661; Corel Corporation, Canada, 2016.

32. Carrilho, E.; Martinez, A. W.; Whitesides, G. M.; Anal. Chem. 2009, 81, 7091.

33. Krauss, S. T.; Holt, V. C.; Landers, J. P.; Sens. Actuators, B 2017, 246, 740 .

34. Bhardwaj, J.; Sharma, A.; Jang, J.; Biosens. Bioelectron. 2019 , $126,36$.

35. Kim, D. B.; Hong, J. M.; Chang, S.-K.; Sens. Actuators, B 2017, 252, 537.

36. Soldat, D. J.; Barak, P.; Lepore, B. J.; J. Chem. Educ. 2009, 86, 617.

37. Pokhrel, P.; Jha, S.; Giri, B.; Pract. Lab. Med. 2020, 21 , e00166. 
38. Whitford, E.; Nzobigeza, W.; Hartwell, S. K.; Anal. Lett. 2020 , $53,2465$.

39. de Oliveira, R. A. G.; Camargo, F.; Pesquero, N. C.; Faria, R. C.; Anal. Chim. Acta 2017, 957, 40.

40. Ansari, N.; Lodha, A.; Mehta, M.; Menon, S. K.; Aust. J. Forensic Sci. 2019, 51, 78.

41. Cerón, J. J.; Martinez-Subiela, S.; Tecles, F.; Caldin, M.; J. Hell. Vet. Med. Soc. 2014, 65, 197.

42. Zygner, W.; Gójska-Zygner, O.; Bąska, P.; Długosz, E.; Vet. Parasitol. 2015, 211, 23.
43. Bellows, J.; Colitz, C. M. H.; Daristotle, L.; Ingram, D. K.; Lepine, A.; Marks, S. L.; Sanderson, S. L.; Tomlinson, J.; Zhang, J.; J. Am. Vet. Med. Assoc. 2015, 246, 77.

44. Camacho, A. T.; Guitian, F. J.; Pallas, E.; Gestal, J. J.; Olmeda, S.; Goethert, H.; Telford III, S.; Spielman, A.; Vet. Res. 2005, 36,713 .

Submitted: April 15, 2020

Published online: September 8, 2020 